\title{
Need for Talent Management and Investigating Its Impact on Organizational Performance of Higher Education Institutes
}

\author{
Dr. GHULAM MURTAZA SHAH \\ Assistant Professor at Badin Campus, University of Sindh. \\ Email: ghulam.murtaza@usindh.edu.pk \\ Tel: 03082903050 \\ NOOR AHMED MEMON \\ $\mathrm{PhD}$ scholar at University of Sindh \\ Email: noor_memon12@ @otmail.com \\ Tel: 03353455799 \\ Dr. GHAZALA TUNIO \\ Lecturer at MUISTD \\ Email: ghazala.tunio@faculty.muet.edu.pk
}

Tel: 03363142393

\begin{abstract}
Human resources' is one of the pivot elements in business enterprises to achieve set goals and objectives of new millennium. Competent and skilled workforce have to be permanent stakeholders of a corporation where they use acquired knowledge and gained skills to achieve set milestones in particular industry. Talent management is the task of attracting, acquiring, developing and retaining skilled workforce to achieve desired goals of corporation. The main objective of this research study is to explore the need for talent management and investigating its impact on the organizational performance of higher education institutes. Three factors of talent management are taken into consideration; talent attraction, talent development and talent retention. Using simple random sampling method, one hundred questionnaires were distributed to academic and administrative heads of three public sector universities in jamshoro city. Data is analyzed using cronbach's alpha, Mean and standard deviation, regression analysis and one sample t test. After analyzing observed data results show positive and significant effect of all three factors of talent management i-e talent attraction, talent development and talent retention on the organizational performance of higher education institutes. It is concluded that talent management is integrated part of better performance and key factor in achieving standards of excellence in higher education institutes. Practicing and implementing talent management will upgrade ranking of institutes at national and international level. Furthermore higher education institutes will show impetus for continuous improvement in imparting quality education to the masses. Faculty and administrative staff of higher education institutes will have opportunity to develop their careers and top management will surely retain skilled employees and have opportunity to grow at par excellence.
\end{abstract}

Keywords: Talent Management, Organizational Performance, Higher Education Institutes.

\section{Introduction}

Human resources is the aggregate quantum of acquired knowledge and skills of the employees work in different business organization. Skills and abilities of human resources must be best utilized to achieve individual and group objectives (Sareen \& Mishra, 2016). Few highlighted challenges face by business 
enterprises are narrated as; increasing globalization, cutthroat competition, merger and consolidation of firms and innovative organizational structures. Human Resources is one of the critical areas to focus on and consider in facing these challenges, organizations need to know potential impact of their employees as strength to cope with challenges of the new millennium (Nasir, Moktar, \& Ariffin, 2017).

Gallardo-Gallardo, Thunnissen, \& Scullion (2020) defined talent management is the systematic process of discovering, attracting, developing and retaining competent pool of employees who can be strategic fit between organizational goals and capabilities (Collings \& Mellahi, 2009) discussed that human capital is important factor in creating and enhancing competitive advantage of the organizations. (Mohammed, 2015) studied that talent is the intuitive quality acquired by few employees in business organization who contribute paramount efforts to achieve desired goals and they play pivotal role in the current and future performance of a corporation. These employees serve as vital source of creating, developing and maintaining competitive advantage of the corporation. A study conducted by (De Smet, Lund, \& Schaninger, 2016) found that most important resource in upcoming two decades in the global world will be the talent; employees who are knowledgeable, technical and smart will be mostly needed in corporations (Blackman \& Kennedy, 2008).

Talent management is the process by which organizations improve productivity and work efficiency though revised processes for acquiring, developing and retaining the competent workforce and to utilize their skills and proficiencies for achieving the long desired goals of the corporations. Barron (2007) narrated that as managers do not have enough talent to improve work efficiency of employees and achieving assigned goals in effective manner, therefore deploying best people on critical positions is utmost important to gain competitive advantage. Talent management ensures right person is posted on right job means the job responsibilities are assigned to the workers based on their education level, acquired skills and experience so they can work efficiently and become potential source of achieving long term goals of the corporations. Organizations engaged in proper functioning of talent management vigorously compete in the market to meet expectations of customers and to achieve long term objectives of profit maximization and shareholders' wealth maximization. For achieving the strategic goals of the corporation, talent management is considered as baseline to perform innovatively and avail external opportunities through internal strength of the corporation (Mohammed, 2015).

Higher education institutes are characterized by major emphasis over last two decades with lot of queries and expectations on work efficiency and overall performance. In this context (Agasisti, 2017) explained that in the first half of twenty first century when higher education institutes particularly the public sector institutes receive budget cuts due to fiscal deficits in the economy of country as well as at the same time rising expectations of people in that society for upgrading ranking of institutes and imparting quality education to the masses have been potential threat to the very existence of institutes in list of top ranking quality education at regional and global level. Societies expect that higher education institutes teach and train their children on the level and standards from where they will work and lead topmost business enterprises in the world. This perspective pushes higher education institutes to plan and execute people and resources with mission of "doing more with less" that may help to meet ever increasing expectations of society and uplift image of the institutes.

Therefore it is imperative to note that need for talent management in higher education institutes is utmost important to achieve desired goals of institutes as well as to meet expectations of society and the country at large.

\section{Research Objectives}

The main objectives of this research study are to,

1. Explore the need for talent management in higher education institutes. 
2. Describe the factors which are essential to be considered in practicing and implementing talent management in higher education institutes.

3. Extrapolate the significant impact of talent management on improving performance of higher education institutes.

\section{Research Questions}

1. Why does talent management needed in higher education institutes?

2. What is the impact of talent attraction on the organizational performance of higher education institutes?

3. What is the impact of talent development on the organizational performance of higher education institutes?

4. What is the impact of talent retention on the organizational performance of higher education institutes?

\section{Literature Review}

Talent management is highly imperative to implement in higher education institutes, in this context (Rudhumbu \& Maphosa, 2015) studied that in the competitive age of businesses higher education industry lag far behind in practicing and implementing talent management. It is perilous for the survival of the industry therefore higher education institutes need to identify this untapped opportunity to strengthen their position in the market and to gain competitive advantage. The need for talent in period of fastest growing and rapidly changing environment requires higher education institutes to set mission of continuous improvement through recruiting, selecting and retaining qualified talent that is significant too for institutional success. Talent means individuals work in organization, which can make positive and significant change in performance of the organization through best utilization of their potential and earned skills. Organizations can grow at desired levels with the sizable contribution of skilled employees therefore investing in talent or skilled employees is necessary for achieving long term goals of the corporation.

In addition it is observed that talent management is key strategic issue in the organization as discussed by (Rudhumbu \& Maphosa, 2015) that organizations failed to highlight value proposition of employees therefore it is important to know the process and application of talent management in attracting, developing and retaining skilled employees of the corporation. Talent management is particularly required in situation during which organizations want to give special assignment or task to the top talent and that is difficult to assign ordinary employees. Talent management is integrated approach that includes personnel planning; forecasting actual number of employees required in near future, acquiring talent and developing them professionally, take certain measures to manage their performance and retain them into organization that is very important and set strategies for their future promotion and career development which is also known as succession planning. All these activities are part of talent management therefore it is termed as integrated approach practiced by organizations to achieve their goals.

Increasing competition among higher education institutes insist top management of public and private sector universities to adopt and implement talent management practices for sustaining and surviving in the contemporary challenging environment. (Rudhumbu \& Maphosa, 2015) explained that talent management reduces the cost of acquiring employees because managing talented pool of employees reduces turnover, ultimately organization will not bear recruitment expenses repeatedly. Talent management provides an opportunity to focus on knowledge management in effective manner as well as its transfer within organization, providing quality education services and new programs or products, provides opportunity to the higher education institutes to create competitive advantage as well as it gives advantage of retaining customers. Currently three trends in higher education institutes are observed which justify the need for talent management, first the gap between performance and reward system for which it is imperative to adopt and practice talent management in institutes, second the less focus on leadership development and succession planning encourage institutes to fill this gap through talent management and the third important 
trend is lack of commitment of higher education institutes to effectively monitor talent management. These three trends highlight the significance of talent management in higher education institutes.

One of the biggest challenges face by companies in modern world is attracting and retaining talent employees, (Rana, 2017) further explained that talent is necessary for optimal drive of successful business enterprises. Top management has to be in connection with high performing employees because it is acknowledged fact that businesses need best people to achieve desired goals and become successful. For the top management it is one of the crucial challenges to find, attract and retain the competent workforce but that is possible to achieve through right tools in the hand. Therefore the study and implication of talent management practices in organizations is compulsory and significant. Workforce planning requires use of talent management in all Human Resources activities include recruiting, selecting, training, retaining and rewarding employees. As companies grow on competitive landscape, the role of managers increased and development of managers become essential activity for success of the organization. Succession planning is necessary for bringing or replacing unskilled or semi skilled employees with skilled and talented youth and to retain talented youth requires adequate understanding in context of job security, compensation, promotion and other benefits. Talent management is therefore important to adopt which is connecting bridge between goals and achievement of set goals.

\section{Talent Management as a strategy for organization}

Tangible resources are not only significant source for achieving set goals of the corporation but managing human resources also act as crucial part of success (Dhanalakshmi \& Gurunathan, 2014) further asserted that tangible resources include land, labor and capital are necessary to compete in twenty first century along with human capital to face global competition and advancement in technology. The knowledge, skills and qualities of employees are components of talent therefore top management strategizes talent management to acquire, retain and maintain competent workforce of employees who are engaged in performing assigned tasks show their earned skills, conceptualize work nature and use technical skills reflect talent.

\section{Talent Management Process}

Employees are integral part of the organization, (Garg \& Rani, 2014) explained that they are engaged in creating value through approved processes of business, innovation, customer service, sales and other activities. Organizations struggle hard for achieving long term objectives therefore they need to perform Human Resources activities include recruitment and selection, training and development, performance appraisal, and compensating the employees.

(Garg \& Rani, 2014) discussed in detail the process given below:

\section{Step 1: Workforce planning}

The talent management process begins with planning in which management plan how to select competent employees based on required skills, competencies and knowledge as well as to be sure that these skills will help to perform productively in tasks assign to them in future.

\section{Step 2: Recruiting}

The process of hiring and appointing employees that becomes one of the competitive strengths of the company. The top management carefully enlist the job responsibilities and qualification requirements for the jobs. To attract talented employees, management has to focus on hiring of talented pool through effective process of recruitment and selection. 


\section{Step 3: On boarding}

Employees have to be trained in a way that helps organizations to achieve their long term objectives. To place right people on right jobs ensure productivity reduces absenteeism and employees turnover.

\section{Step 4: Performance Management}

Employees performance have to be continuously monitored and improved through setting performance standards and then measure the actual performance with the standards. Management will monitor if there is any discrepancy in the performance, it has to be corrected and rectified. This process adequately achieves the task of performance management.

\section{Step 5: Succession planning}

As organizations grow, management has to place right people on key positions. Succession planning involves careful study of the organizational business strategies and then to identify right candidates for their positions. As it is also one of the steps of talent management, organizations need to thoroughly review the process and identify important positions to be filled with deserving employees.

\section{Talent Management Contemporary view}

Dahshan, Keshk, \& Dorgham (2018) elaborated that talent management in today's perspective understood as process by which we recruit, select, train and develop talent, highly skilled employees are selected to be deployed on deserved positions in order to maintain the talented workforce to increase workers productivity. Three elements of talent management are taken into consideration i-e attracting, developing and retaining competent workers which will enable organizations to pull right skills into the organization. Management has to give flexi hours at workplace to attract talented pool of employees so the best employees feel more convenient to work with that organization. This approach of management makes their organization more attractive for job seekers and no more efforts required to be taken to attract talented pool of employees. It creates competitive advantage for the organization.

In contemporary business organizations learning culture is prerequisite for growth and development of that organization. Continuous change is part of total quality management that has to be achieved and maintained through talent management process. Attracting and retaining talented employees result in positive change in the organization that lead to develop and maintain competitive advantage.

Dahshan et al., (2018) further explained that employee retention is one of the prominent concerns of organizations, to maintain the talented pool of employees require organizations to develop, promote and reward them in such an attractive manner that motivates them to stay committed with the organization. Talent turnover is however more expensive and unaffordable for organizations, the replacement cost of employees, cost of repeat process of attracting, recruiting, developing and training best employees of the corporation will become more time taking and highly expensive.

There are a lot of advantages of talent management as discussed by (Dahshan et al., 2018) include performance improvement, maintaining competitive advantage, enhance work productivity, promote learning environment and introduce as well as implement positive change that lead to continuous improvement and work excellence. Most of the organizations failed due to poor planning and ineffective implementation of formulated strategies, unjust work processes and undesired attitude towards positive change. Therefore it is need of an hour to implement and maintain talent management program to achieve long term goals of the corporations. 


\section{Importance of the Talent Management}

To highlight the importance of talent management, (Nosh Abadi, Khadem, \& Sadeghnia, 2015) explained that those organizations which practice and implement talent management result in selection of most competent and talented employees as well as to increase their commitment to work with the same organization. The best employees will be selected for the key posts and right person will occupy right position in the organization.

Nowadays organizations put more efforts to implement talent management processes because it is directly linked with organizations superior performance. In addition, organizations noted that their earning profits increased manifold therefore it indicates that organizations perform better which is the outcome of talent management. The skilled employees contribute their input in the value creation which helps to create and maintain competitive advantage. Therefore the financial worth of the organization depends on availability and expertise of skilled employees, this overall process will grow organizations more rapidly. To grow and develop in dynamic and competitive business environment, organizations need to estimate the worth of talent management.

\section{Organizational Performance}

Almatrooshi, Singh, \& Farouk (2016) discussed that performance of any organization depends on evaluation of its goals and objectives achieved. Furthermore it is highlighted that performance can be determined through comparing actual outcomes with intended outcomes. As for as effectiveness of the organizations is concerned; it can be determined through efficiency of its employees. Honest, dedicated and competent employees can be pooled and retained if effective leadership exists to manage organizations. Employees' performance can be measured through different factors, few factors are under control of management however they cannot influence and modify all factors in employees. Therefore main elements of organizational performance to achieve efficiency and effectiveness are employees' performance and leadership.

Skilled leaders influence their followers in changing behaviors which help achieving their assigned tasks. Therefore key factor in achieving goals and objectives of any organization is its leadership. The way organization is governed by top management determines its fate and future. Because leaders create organizational culture and provide environment that motivate employees to perform better.

\section{Research Hypothesis}

H1: Talent management is needed in higher education institutes.

$\mathrm{H} 2$ : Factors of talent management are essential to be practiced and implemented in higher education institutes.

H2A: Talent attraction has positive and significant effect on the organizational performance of higher education institutes.

H2B: Talent development has positive and significant effect on the performance of higher education institutes.

H2C: Talent retention has positive and significant effect on the performance of higher education institutes. 


\section{Conceptual Framework}

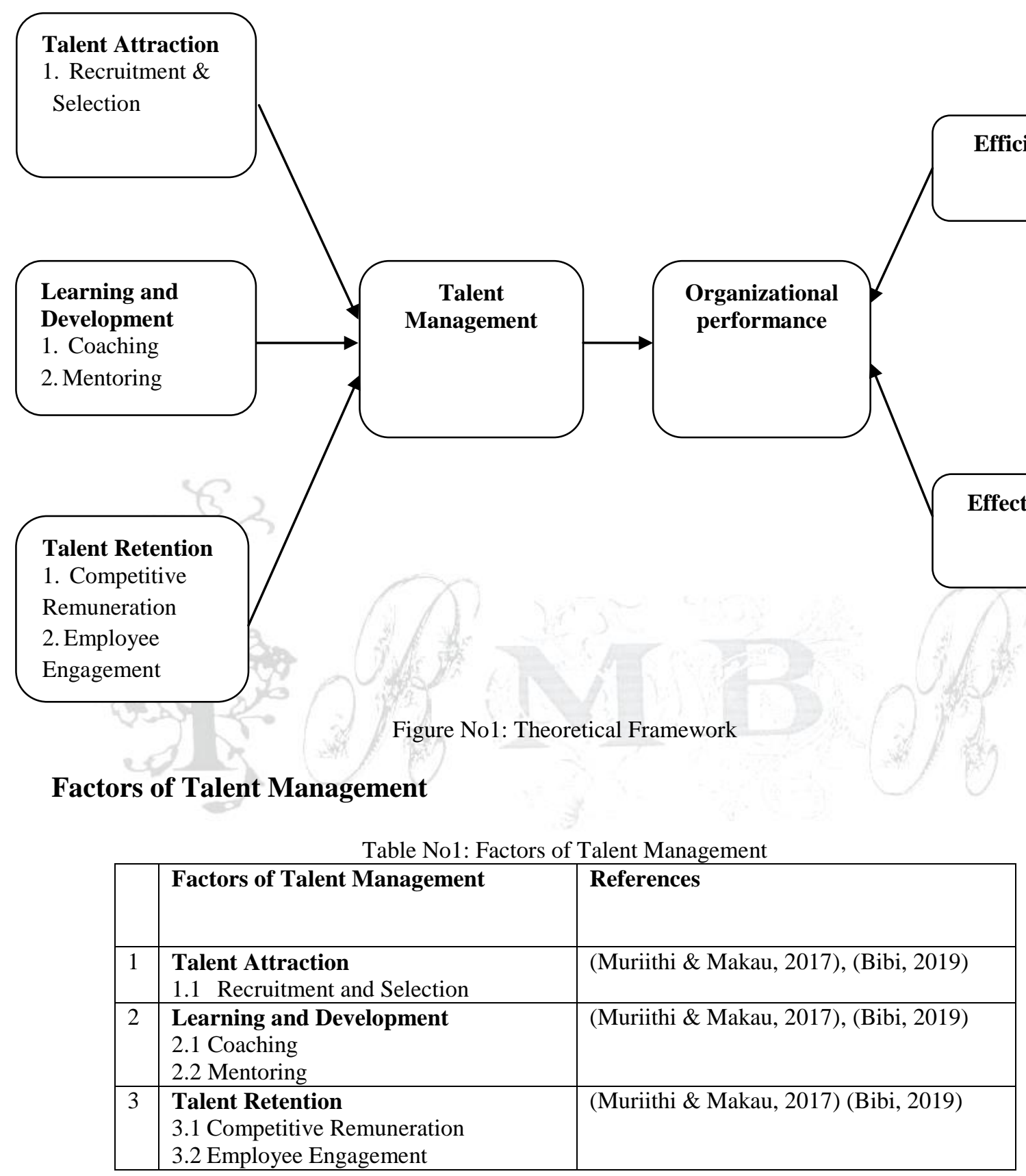

\section{Talent Attraction}

One of the important and beginning steps in talent management process is recruitment and selection (Alruwaili, 2018) Organizations have many ways to attract talented pool but recruitment and selection is one of the specified ways to attract competent pool of candidates who will serve organization as strength to support that organization in achieving their set goals and become successful (Rabbi, Ahad, Kousar, \& Ali, 
2015). Recruitment stage attracts talented pool of applicants that help organization to know eligibility of applicants against the vacant posts and selection stage includes assessment of required skills in applicants which confirm their abilities to fulfill assigned work in effective manner and organization will become confident that right person is selected against right job (Oaya, Ogbu, \& Remilekun, 2017)

\section{Learning and Development}

Learning and development is very important phase for the employees in maintaining their superior performance in the competitive age of business enterprises. It is also very crucial for organizational success to respond continuously changing environment (Rabbi et al., 2015). Coaching and mentoring are two important elements of learning and development as explained by (Khakwani, Aslam, Azhar, \& Mateen, 2012) that coaching and mentoring improve employees performance and those employees who have less skills to perform their assigned tasks needed to be guided and supported by their managers to achieve their existing and anticipated performance at workplace.

\section{Talent Retention}

Retention of talent is one of the important challenges face by most of the business organizations in twenty first century. (Mabaso, 2016) further explained that to retain the talented employees, organizations need to give very attractive compensation packages to the employees for successfully achieving the goals of the corporation. Because achieving goals effectively ensures capability of the organizations to give attractive compensation packages to the employees. On the other hand Employee engagement involves determining behavior of employees and their emotional and intellectual attachment with the organizational group. Those employees who are committed and loyal with their organization intended to stay long with their employer always perform better. As the talent of competent employees acknowledged and rewarded, they will make positive difference in achieving the goals and objectives of the corporation (Mohammed, 2015)

\section{Research Methodology}

\section{Data collection}
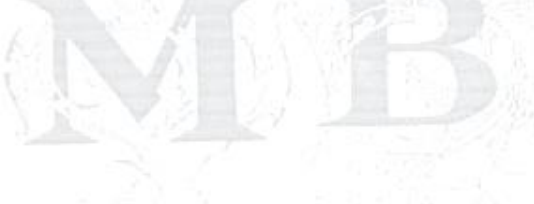

This research involves use of primary data for investigating and analyzing the talent attraction, development and retention of employees. Closed ended questionnaire adopted from the (Dahshan et al., 2018) and little bit modified, the questionnaire is developed on five points likert scale and comprised of thirty one items. Ten items each for Talent attraction and Talent development however eleven items are included for Talent retention. Thirteen items on efficiency and effectiveness of organizational performance are adopted from (Naik, 2012). Data was collected from Directors, Registrars, Additional and Deputy Registrars, Head of departments, Pro Vice chancellors and Deans of different faculties and administrative units of three universities at Jamshoro city.

\section{Population and Sample}

Three public sector universities in Jamshoro have been taken as sampling frame. Total number of population including Directors/chairpersons, Deans of faculties, Pro Vice Chancellors, Registrars and other Directors of different administrative departments is two hundred and nine (209). Out of total population one hundred (100) respondents taken as sample. Sixty (60) questionnaires were distributed in Sindh University and remaining forty questionnaires distributed in two universities, 20 in Mehran University and 20 in Liaquat University of medical and health sciences Jamshoro. All questionnaires were adequately filled and completely returned. Using simple random sampling method, one hundred questionnaires were distributed among respondents. First thirty (30) questionnaires collected for reliability analysis using Chronbach alpha, the technique used to measure internal consistency of responses related to different items included in questionnaire. After getting reliable results of measuring internal consistency through cronbach 
alpha, remaining seventy (70) questionnaires were distributed among residual respondents out of one hundred (100) sample.

\section{Data Analysis}

The data was analyzed using chronbach alpha, descriptive statistics include mean and standard deviation as well as regression analysis and one sample $t$ test.

\section{Results of Chronbach Alpha}

For measuring the internal consistency among items included in research questionnaire, (Bryman, 2016) stated that Cronbach alpha is a statistical technique used to measure the internal consistency among items. The values determined for interpreting results of cronbach alpha, as explained by (Taber, 2018), specified as excellent (0.93-0.94), strong (0.91-0.93), reliable (0.84-0.90), robust (0.81), Relatively high (0.70-0.77), satisfactory (0.61-0.69).

Following table shows the results of cronbach alpha analysis of three factors of Talent management.

\section{Cronbach alpha analysis of Talent Attraction}

Table 1: Reliability Statistics

\begin{tabular}{|c|c|c|}
\hline $\begin{array}{c}\text { Cronbach's } \\
\text { Alpha }\end{array}$ & $\begin{array}{c}\text { Cronbach's Alpha Based } \\
\text { on Standardized Items }\end{array}$ & N of Items \\
\hline .729 & .682 & 10 \\
\hline
\end{tabular}

The above table shows cronbach alpha analysis of Talent management factor i-e Talent attraction. Talent attraction included ten items and thirty questionnaires were distributed among respondents, the results show $72 \%$ value of cronbach's alpha indicated that internal consistency among items is relatively high and questionnaire is reliable to be distributed among rest of the population sample.

Cronbach Alpha analysis of Talent Development

Table 2: Reliability Statistics

\begin{tabular}{|c|c|c|}
\hline Cronbach's Alpha & $\begin{array}{c}\text { Cronbach's Alpha Based on } \\
\text { Standardized Items }\end{array}$ & N of Items \\
\hline .747 & .723 & 10 \\
\hline
\end{tabular}

The above table shows Chronbach alpha analysis of Talent management factor i-e Talent development. Talent development comprised of ten items included in the questionnaire, thirty questionnaires were distributed among respondents. The results show 74\% value of cronbach's alpha indicated that internal consistency among items is relatively high and questionnaire shows reliability for further distribution among population sample.

\section{Cronbach alpha analysis of Talent Retention}

Table 3: Reliability Statistics

\begin{tabular}{|c|c|c|}
\hline $\begin{array}{c}\text { Cronbach's } \\
\text { Alpha }\end{array}$ & $\begin{array}{c}\text { Cronbach's Alpha Based on } \\
\text { Standardized Items }\end{array}$ & N of Items \\
\hline .773 & .749 & 11 \\
\hline
\end{tabular}


The above results show the cronbach's alpha analysis of Talent management factor i-e Talent retention. Talent retention comprised of eleven items included the questionnaire were distributed among thirty respondents. The results show 77\% value of cronbach's alpha indicated that internal consistency among items is relatively high and the questionnaire is reliable to be distributed among rest of the respondents in population sample.

\section{Cronbach alpha analysis of organizational performance}

Table 4: Reliability Statistics

\begin{tabular}{|c|c|c|}
\hline Cronbach's Alpha & $\begin{array}{c}\text { Cronbach's Alpha Based on } \\
\text { Standardized Items }\end{array}$ & N of Items \\
\hline .842 & .820 & 13 \\
\hline
\end{tabular}

Cronbach alpha analysis results of organizational performance show internal consistency of thirteen items, the alpha value is $84 \%$ which is reliable.

\section{Results of Descriptive Statistics}

(Barde \& Barde, 2012) stated that sample is the mean value of all observations; the mean value shows average responses of the respondents on observed data. Standard deviation is the static measure of the dispersion in a dataset relative to its mean.

Following are the data analysis results of Mean and Standard deviation

Table 5: Descriptive Statistics

\begin{tabular}{|l|c|c|c|c|c|}
\hline & $\mathrm{N}$ & Minimum & Maximum & Mean & Std. Deviation \\
\hline TalentAttraction & 100 & 3.00 & 4.60 & 3.8340 & .58762 \\
TalentDevelop & 100 & 2.90 & 5.00 & 4.0370 & .63971 \\
TalentRetention & 100 & 2.82 & 4.82 & 3.9645 & .59478 \\
ORGPER & 100 & 2.31 & 5.00 & 3.8238 & .66553 \\
Valid N (listwise) & 100 & & & & \\
\hline
\end{tabular}

In above table the mean of all three independent variables i-e talent attraction, talent development, talent retention and one dependent variable i-e organizational performance mean values are greater than 3.80 near to 4.00 which show majority of the respondents agreed that all three factors of talent management are essential for improving the organizational performance of higher education institutes. The standard deviation values are less than one show very low deviation of observed data from the mean value.

\section{Regression Analysis}

Bryman, (2016) discussed regression analysis is a statistical tool that is used to describe the relationship between dependent and independent variables. To measure the impact of talent management on organizational performance of higher education institutes, regression analysis is an important data analysis technique.

\section{Results}

In below table $\mathrm{R}$ square value $77.9 \%$ show magnificent change in organizational performance is explained by three factors of talent management, i-e talent attraction, talent development and talent retention. It is interpreted that almost $78 \%$ change or improvement in performance of higher education institutes is due to 
implementing talent management, more specifically talent attraction, talent development and talent retention.

Table 6: Model Summary

\begin{tabular}{|c|c|c|c|c|}
\hline Model & $\mathrm{R}$ & $\mathrm{R}$ Square & Adjusted R Square & $\begin{array}{c}\text { Std. Error of the } \\
\text { Estimate }\end{array}$ \\
\hline 1 & $.883^{\mathrm{a}}$ & .779 & .772 & .31771 \\
\hline
\end{tabular}

a. Predictors: (Constant), TalentRetention, TalentDevelop, TalentAttraction

Table 7: ANOVA $^{\mathrm{a}}$

\begin{tabular}{|c|c|c|c|c|c|}
\hline Model & Sum of Squares & $\mathrm{df}$ & Mean Square & $\mathrm{F}$ & Sig. \\
\hline \multirow{3}{*}{$\begin{array}{c}\text { Regression } \\
\text { Residual } \\
\text { Total } \\
\end{array}$} & 34.160 & 3 & 11.387 & 112.806 & $.000^{\mathrm{b}}$ \\
\hline & 9.690 & 96 & .101 & & \\
\hline & 43.850 & 99 & & & \\
\hline
\end{tabular}

a. Dependent Variable: ORGPER

b. Predictors: (Constant), TalentRetention, TalentDevelop, TalentAttraction

Table 7 confirms the model is best fit as significant $\mathrm{p}$ value is .000 which is less than 0.05. In ANOVA table it is observed that three predictors have positive and significant impact on the performance of higher education institutes.

Table 8: Coefficients ${ }^{\mathrm{a}}$

\begin{tabular}{|c|c|c|c|c|c|c|c|c|}
\hline \multirow{2}{*}{\multicolumn{2}{|c|}{ Model }} & \multicolumn{2}{|c|}{$\begin{array}{c}\text { Unstandardized } \\
\text { Coefficients } \\
\end{array}$} & $\begin{array}{c}\text { Standardized } \\
\text { Coefficients }\end{array}$ & \multirow[t]{2}{*}{$\mathrm{t}$} & \multirow[t]{2}{*}{ Sig. } & \multicolumn{2}{|c|}{$\begin{array}{c}95.0 \% \text { Confidence } \\
\text { Interval for B }\end{array}$} \\
\hline & & B & $\begin{array}{l}\text { Std. } \\
\text { Error }\end{array}$ & Beta & & & $\begin{array}{l}\text { Lower } \\
\text { Bound }\end{array}$ & Upper Bound \\
\hline \multirow{4}{*}{1} & (Constant) & -.737 & .372 & & -1.978 & .051 & -1.476 & .003 \\
\hline & TalentAttraction & .435 & .065 & .384 & 6.640 & .000 & .305 & .565 \\
\hline & TalentDevelop & .036 & .053 & .035 & .687 & .494 & -.068 & .140 \\
\hline & TalentRetention & .693 & .067 & .619 & 10.385 & .000 & .561 & .826 \\
\hline
\end{tabular}

a. Dependent Variable: ORGPER

Above table shows Beta coefficients and their significance to determine the acceptance or rejection of alternate hypotheses.

H2A. Talent attraction has positive and significant impact on organizational performance of higher education institutes, it is accepted because Beta value is positive .435 and significant $p$ value is .000 which is less than 0.05 .

H2B. Talent development has positive and significant impact on organizational performance of higher education institutes, it is partially accepted because Beta value is positive, i-e .036 however significant $\mathrm{p}$ value is .494 which is greater than 0.05 .

H3A. Talent retention has positive and significant effect on organizational performance of higher education institutes, it is accepted as Beta value is .693 which is positive and significant p value is .000 which is less than 0.05 . 


\section{One Sample t test analysis}

One sample $t$ test is used to determine the mean difference between standard mean and sample mean to know the deviation which will evaluate the significance of factors used (Bryman, 2016). This test will analyze whether talent attraction, talent development and talent retention are significant factors for talent management?

\section{One sample $t$ test analysis of Talent Attraction}

Table 9: One-Sample Statistics

\begin{tabular}{|c|c|c|c|c|}
\hline & $\mathrm{N}$ & Mean & Std. Deviation & Std. Error Mean \\
\hline TalentAttraction & 100 & 3.8340 & .58762 & .05876 \\
\hline
\end{tabular}

Table 10: One-Sample Test

\begin{tabular}{|c|c|c|c|c|c|c|}
\hline & \multicolumn{6}{|c|}{ Test Value $=3$} \\
\hline & \multirow[t]{2}{*}{$\mathrm{T}$} & \multirow[t]{2}{*}{$\mathrm{df}$} & \multirow[t]{2}{*}{ Sig. (2-tailed) } & \multirow[t]{2}{*}{$\begin{array}{c}\text { Mean } \\
\text { Difference }\end{array}$} & \multicolumn{2}{|c|}{$\begin{array}{l}\text { 95\% Confidence Interval of the } \\
\text { Difference }\end{array}$} \\
\hline & & & & & Lower & Upper \\
\hline TalentAttraction & 14.193 & 99 & .000 & .83400 & .7174 & .9506 \\
\hline
\end{tabular}

Table 9 and 10 show one sample $t$ test of talent attraction as first component of talent management process. In above two tables the test value of mean is 3 , and the mean of one sample $t$ test in table 1.5 is 3.83 which shows the mean difference is 0.83 indicate the observed mean is close to the test value and therefore the component is significant. The significant two tailed $\mathrm{p}$ value in table 1.6 is 0.000 which is less than 0.05 means talent attraction is significant component to be used as part of talent management process.

\section{One sample $t$ test analysis of Talent Development}

Table No 11: One-Sample Statistics

\begin{tabular}{|l|r|r|r|r|}
\hline & \multicolumn{1}{|c|}{$\mathrm{N}$} & Mean & Std. Deviation & Std. Error Mean \\
\hline TalentDevelop & 100 & 4.0370 & .63971 & .06397 \\
\hline
\end{tabular}

Table No 12: One-Sample Test

\begin{tabular}{|c|c|c|c|c|c|c|}
\hline \multirow{2}{*}{} & \multicolumn{9}{|c|}{$\mathrm{df}$} & Sig. (2-tailed) & $\begin{array}{c}\text { Mean } \\
\text { Difference }\end{array}$ & $\begin{array}{c}\text { 95\% Confidence Interval of the } \\
\text { Difference }\end{array}$ \\
\cline { 5 - 7 } & & & & & Lower & Upper \\
\hline TalentDevelop & 16.211 & 99 & .000 & 1.03700 & .9101 & 1.1639 \\
\hline
\end{tabular}

Table 11 and 12 show results of one sample t test analysis of talent development. The test value of one sample test in table 11 is 3 and the mean of one sample statistics in table 1.7 is 4.03 so the mean difference is 1.03 indicate significance of the component talent development in the talent management process. The significant two tailed $\mathrm{p}$ value in table 12 is 0.000 which is less than 0.05 means talent development is one of the important components of talent management process. 


\section{One sample $t$ test analysis of talent retention}

Table 13: One-Sample Statistics

\begin{tabular}{|l|c|c|c|c|}
\hline & $\mathrm{N}$ & Mean & Std. Deviation & Std. Error Mean \\
\hline TalentRetention & 100 & 3.9645 & .59478 & .05948 \\
\hline
\end{tabular}

Table 14: One-Sample Test

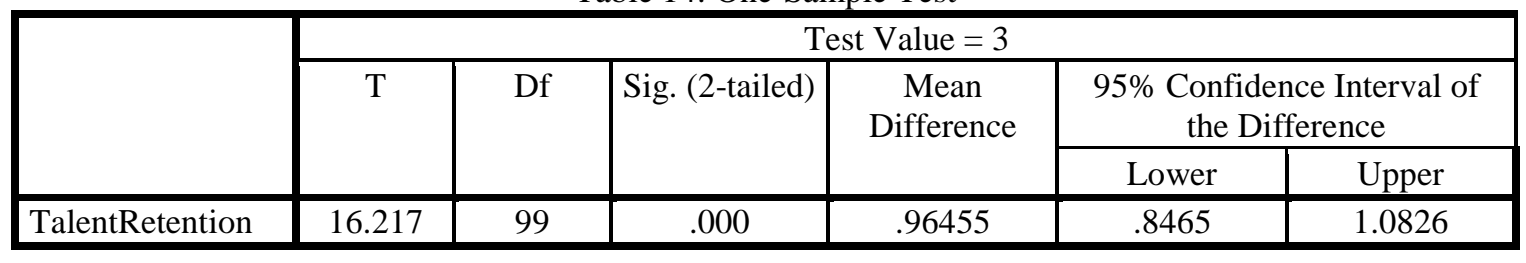

Table 13 and 14 show one sample $t$ test analysis of talent retention. The test value is 3 in table 1.10 and the observed mean in table 13 show 3.96 which shows the mean difference is 0.96 which is very near to test value or standard value indicate significance of another component of talent management i-e talent retention. The significant $p$ value in table 1.10 is 0.000 which is less than 0.05 indicate that talent retention is another significant component of talent management process.

The one sample $t$ test was used to measure the significance of three main components of talent management i-e talent attraction, talent development and talent retention. Three components are important to be adopted and practiced in higher education institutes which highlight the need for talent management in these institutes. The respondents are totally agreed with their valid opinion that employees in higher education institutes must undergo talent management process which will also affect on overall performance of the higher education institutes.

\section{Discussion and Conclusion}

Higher education institutes identified one of the key factors in achieving set goals and objectives i-e talent management. All three factors of talent management, i-e talent attraction, talent development and talent retention have positive and significant effect on the organizational performance of higher education institutes. The significant mean and very low standard deviation of all three factors as well as $77 \% \mathrm{R}$ squared, significant $\mathrm{p}$ value .000 and positive beta of each factor in relation to organizational performance interprets direct and major influence of talent attraction, development and retention on performance efficiency and effectiveness of higher education institutes. (Mohammed, 2015) endorsed results of proposed study who concluded positive and significant association of talent management with employee engagement, retention, value addition and organizational performance. (Dhanalakshmi \& Gurunathan, 2014) also endorsed results of proposed study, concluded that properly implemented talent management results in effective employee engagement which in turn positively affect organizational performance. (Sareen \& Mishra, 2016) discussed that organizations can achieve growth and profitability if they implement talent management practices to attract and retain skilled employees. (Garg \& Rani, 2014) endorsed that practicing talent management in organizations increases productivity because it gives linkage between employees' skills and organizational goals.

Higher education institutes perform better as their skilled and highly qualified employees or talented workforce contribute more to achieve desired goals. Skilled employees prefer to work long with organization if they are being properly guided for their work, receive attractive rewards for their work done. To retain talented employees is one of the major challenges faced by higher educational institutes in twenty first century. Therefore it is need of an hour to understand, practice and implement talent management in the recruitment and selection, development of employees and other HR activities of higher 
education institutes which will upgrade their academic performance and improve quality of imparting higher education to the pupils at graduate, postgraduate and doctoral levels. This research not only explored need for talent management in higher education institutes but also analyzed impact of adopting and practicing talent attraction, talent development and talent retention of employees on the overall performance of higher education institutes.

\section{Limitations}

This research does not focus on all higher educational institutes of Sindh province in particular and rest of the country in general. The researcher only collected data from three public sector universities of Jamshoro i-e Sindh University main campus Jamshoro, Mehran university of Engineering and Technology Jamshoro and Liaquat University of medical and health sciences Jamshoro. Other willing researchers on talent management can study the topic in broader perspective at country level. Further private sector higher education institutes and other business enterprises can also be taken as case study to investigate the impact of talent management on organizational performance.

\section{Practical Implications}

This research study is handy and meaningful for top management of higher education institutes for improving performance and achieving desired goals. Directors, Deans, Pro-Vice Chancellors of adjacent campuses, Vice chancellors, Registrars, Directors ORIC and all other heads of different departments and sections recruit, select and compensate their subordinates on practices of talent management, in return they expect better and improved performance. Practicing and implementing talent management will upgrade ranking of institutes at national and international level. Furthermore higher education institutes will show impetus for continuous improvement in imparting quality education to the masses. Faculty and administrative staff of higher education institutes will have opportunity to grow their careers and top management will surely retain skilled employees and develop at par excellence.

\section{References}

Agasisti, T. (2017). Management of higher education institutions and the evaluation of their efficiency and performance: Taylor \& Francis.

Almatrooshi, B., Singh, S. K., \& Farouk, S. (2016). Determinants of organizational performance: a proposed framework. International Journal of Productivity and Performance Management.

Alruwaili, N. F. (2018). Talent management and talent building in upgrading employee performance. European Journal of Sustainable Development, 7(1), 98-98.

Barde, M. P., \& Barde, P. J. (2012). What to use to express the variability of data: Standard deviation or standard error of mean? Perspectives in clinical research, 3(3), 113.

Barron, M. (2007). Analyzing critical positions for talent needs. Organization Development Journal, 25(4), P115.

Bibi, M. (2019). Impact of talent management practices on employee performance: an empirical study among healthcare employees. SEISENSE Journal of Management, 2(1), 22-32.

Blackman, D., \& Kennedy, M. (2008). Talent management: developing or preventing knowledge and capability? : Citeseer.

Bryman, A. (2016). Social research methods: Oxford university press.

Collings, D. G., \& Mellahi, K. (2009). Strategic talent management: A review and research agenda. Human resource management review, 19(4), 304-313.

Dahshan, M., Keshk, L., \& Dorgham, L. S. (2018). Talent management and its effect on organization performance among nurses at shebin el-kom hospitals. International Journal of Nursing, 5(2), 108-123.

De Smet, A., Lund, S., \& Schaninger, W. (2016). Organizing for the future. McKinsey Quarterly, 1, 30-43. 
Dhanalakshmi, R., \& Gurunathan, K. B. (2014). A study on talent management as a strategy to influence employee engagement and its affect on the organizational outcome. International Journal of Business and Administration Research Review, 2(4), 183-186.

Gallardo-Gallardo, E., Thunnissen, M., \& Scullion, H. (2020). Talent management: Context matters: Taylor $\&$ Francis.

Garg, D., \& Rani, K. (2014). Talent management: Empirical research results. International Journal of Management and Commerce Innovations, 2(1), 289-295.

Khakwani, S., Aslam, H. D., Azhar, M. S., \& Mateen, M. M. (2012). Coaching and mentoring for enhanced learning of human resources in organizations:(Rapid multiplication of workplace learning to improve individual performance). Journal of Educational and Social Research, 2(1), 257-257.

Mabaso, C. (2016). The Influence of Compensation and Performance Management on Talent Retention. Global Journal of Management And Business Research.

Mohammed, A. (2015). The impact of talent management on employee engagement, retention and value addition in achieving organizational performance. International Journal of Core Engineering \& Management (IJCEM), 1(12), 1-4.

Muriithi, F. W., \& Makau, M. S. (2017). Talent Management: A conceptual framework from Review of Literature and a research agenda. Journal of Human Resource Management, 5(6), 90-94.

Naik, S. (2012). Impact of Talent Management on The Performance of an Organization with Special Reference to ABG, Pipapav, Bharati Shipbuilding Industries. A Report.

Nasir, Y. S., Moktar, S., \& Ariffin, A. S. (2017). Effectiveness of talent management to improving organisational performance in government owned bank. Journal of Advanced Research in Business and Management Studies, 7(1), 32-38.

Nosh Abadi, M. F., Khadem, S. M., \& Sadeghnia, A. (2015). Talent management and maintaining talented human resource: a case study in Kashan University of Medical Sciences. European Online Journal of Natural and Social Sciences: Proceedings, $2(3$ (s)), pp. 3446-3457.

Oaya, Z. C. T., Ogbu, J., \& Remilekun, G. (2017). Impact of Recruitment and Selection Strategy on Employees Performance: A Study of Three Selected Manufacturing Companies in Nigeria. International Journal of Innovation and Economic Development, 3(3), 32-42.

Rabbi, F., Ahad, N., Kousar, T., \& Ali, T. (2015). Talent management as a source of competitive advantage. Journal of Asian business strategy, 5(9), 208.

Rudhumbu, N., \& Maphosa, C. (2015). Implementation of talent management strategies in higher education: evidence from Botswana. Journal of Human Ecology, 49(1-2), 21-32.

Sareen, P., \& Mishra, S. (2016). A study of talent management and its impact on performance of organizations. Journal of Business and Management, 18(12), 66-73.

Taber, K. S. (2018). The use of Cronbach's alpha when developing and reporting research instruments in science education. Research in Science Education, 48(6), 1273-1296. 